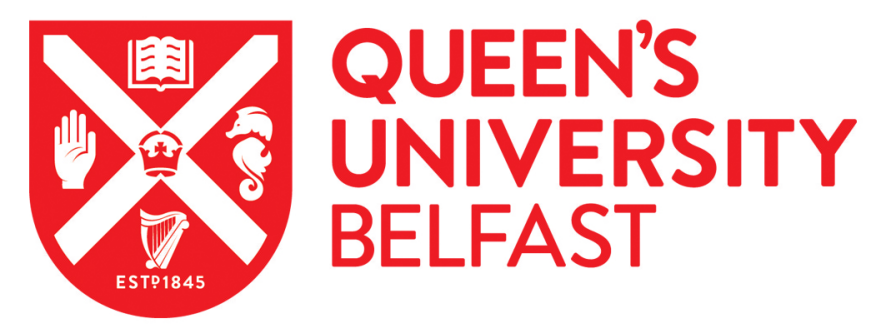

\title{
"Good news everyone", the natives have returned: Assemblages of European flat oysters make a reappearance in Belfast Lough after a century of absence.
}

Smyth, D., Hayden-Hughes, M., Alexander, J., Bayford, P., \& Kregting, L. (2021). "Good news everyone", the natives have returned: Assemblages of European flat oysters make a reappearance in Belfast Lough after a century of absence. Regional Studies in Marine Science, 41, [101585].

https://doi.org/10.1016/j.rsma.2020.101585

\section{Published in:}

Regional Studies in Marine Science

Document Version:

Peer reviewed version

Queen's University Belfast - Research Portal:

Link to publication record in Queen's University Belfast Research Portal

\section{Publisher rights}

Copyright 2020 Elsevier.

This manuscript is distributed under a Creative Commons Attribution-NonCommercial-NoDerivs License

(https://creativecommons.org/licenses/by-nc-nd/4.0/), which permits distribution and reproduction for non-commercial purposes, provided the author and source are cited

\section{General rights}

Copyright for the publications made accessible via the Queen's University Belfast Research Portal is retained by the author(s) and / or other copyright owners and it is a condition of accessing these publications that users recognise and abide by the legal requirements associated with these rights.

Take down policy

The Research Portal is Queen's institutional repository that provides access to Queen's research output. Every effort has been made to ensure that content in the Research Portal does not infringe any person's rights, or applicable UK laws. If you discover content in the

Research Portal that you believe breaches copyright or violates any law, please contact openaccess@qub.ac.uk. 
"Good news everyone", the natives have returned: Assemblages of European flat oysters make a reappearance in Belfast Lough after a century of absence

4 David Smyth ${ }^{{ }^{*}}$, Maria Hayden-Hughes ${ }^{a}$, Jenna Alexander ${ }^{a}$, Philippa Bayford ${ }^{a}$ and Louise $5 \quad$ Kregting $^{\mathrm{b}}$

$6 \quad$ a School of Ocean Science, Bangor University Wales, LL59 5AB.

7 b School of Natural and Built Environment, Queen's University Belfast, Northern Ireland, 8 United Kingdom

$9 *$ Correspondence E-mail: d.smyth@bangor.ac.uk.

11 Keywords: European flat oyster, Ostrea edulis, re-established, unassisted native oyster 12 recovery

\section{Abstract}

Belfast Lough in Northern Ireland like most estuarine systems in the UK and Europe once supported a prolific Ostrea edulis fishery. However, the oyster was considered locally extinct from the Lough by the early 1900s. Numerous ecological surveys over the next 100 years failed to document one living specimen. Unsubstantiated sightings of solitary $O$. edulis along the Loughs intertidal were recently conveyed to the author. It was considered necessary to investigate these reports and as a result the presence of small assemblages of European flat 
native oysters was confirmed. Hypotheses as to why the oysters have returned unaided are discussed with the aim to investigate these at depth in the future.

\section{Introduction}

The demise of the European native oyster Ostrea edulis, from that of a keystone species to an obscure bivalve, throughout the majority of its natural range has been well documented (Thurstan et al., 2013; Farinas-Franco et al., 2018; Pogoda et al., 2019). A number of factors have been associated with the demise of global estuarine oyster populations between the mid-1700s and late-1800s; industrial pollutants, coastal development, increases in sewage outflow and growing urbanization (Korringa, 1946; Maggenis et al., 1983). However, the most prominent drivers related to historical losses in native oyster populations have been identified as overfishing and disease (Yonge, 1960). The combination of these stressors devastated stocks to such an extent that the oyster still remains extinct from many of its historically prolific sites $>100$ years after its disappearance (Pogoda, 2019). Instances whereby the native oyster has returned unaided are rare and those which have been documented were often the result of an aquaculture spawning event (Kennedy and Roberts 1999; 2006; Smyth et al., 2017). Pro-active interventions using stock augmentation are therefore considered vital if $O$. edulis is to make a return to its historic locations (Thurstan et al., 2013). As a result, numerous O. edulis restoration programmes are currently underway throughout the UK and Europe in an attempt to address the oysters decline (Pogoda et al., 2019).

Belfast Lough in Northern Ireland once accommodated a substantial population of native oysters (Mskimin, 1829). The first report of a recognised commercial oyster fishery in the Lough was in 1780 when it was stated that "the oyster is dredged from September to May by 27 boats and 123 fishers all of whom can read with the exception of two" (Mskimin, 1829). 
The report also implied that oyster stocks were in a state of decline as a boat could dredge 800 to 1,200 large oysters a day at a price of $4-7$ shillings per 100 in the year of 1800 . However, by 1819 , a boat was dredging between 100 and 300 oysters a day at a price of 8-18 shillings per 100 (Mskimin, 1829). Since the official closure of the Belfast Lough fishery in 1903 there have been no reports of wild $O$. edulis, no aquaculture stocks and no restoration attempts (Ferreira et al., 2007; CEFAS, 2017).

An investigation into the 1897, 1898 and 1901 enteric fever epidemics of Belfast City by the physician, Mair (1908) stated that, "the working class of Belfast were heavy consumers of shellfish including periwinkles, cockles, and mussels but not oysters as these have been practically extinct for many years". The Irish Fisheries Commission considered the Belfast Lough oyster fishery officially closed in their report of 1903 (Browne, 1903; Kennedy and Roberts, 1999). The renowned malacologist N.F. McMillan did not record any living O. edulis specimens during meticulous surveys of the Lough between 1928 and 1929 (MacDonald, 1947). Gee and Wilson (1981) some fifty years later still failed to document the oyster on a comprehensive molluscan species list and more recently, in 1999, malacologists from the Ulster Museum Belfast could not detect any living native oysters during an extensive subtidal and intertidal investigation (Habitats.org). The 2002 Joint Nature Conservation Committee survey of the Lough was also unsuccessful in locating any live specimens and in 2017 the Sanitary Review of Belfast Lough only documented the presence of sub-fossil shell (Parr and Ager, 2003; CEFAS, 2017).

These historical accounts and surveys confirm the European native oyster as being absent from Belfast Lough for $>100$ years. However, the author was recently made aware of unconfirmed reports of solitary 0 . edulis along the intertidal zone of the Lough (pers. comm. 
67 Gilmore, 2018; pers. comm. Hewitt, 2019). Consequently, it was considered necessary to

68

69

70 investigate these unsubstantiated sightings of individual $O$. edulis to ascertain if an unassisted recovery had indeed occurred after more than a century.

\section{Materials and methods}

\subsection{Site}

Belfast Lough is a fully marine inshore body of water located on the east coast of Northern Ireland (Fig. 1). The Lough is a relatively shallow marine bay $\sim 21 \mathrm{~km}$ long and $11 \mathrm{~km}$ wide, with a max depth of $23 \mathrm{~m}$ covering an area of $130 \mathrm{~km}^{2}$ with annual seawater temperatures of between 2 to $21{ }^{\circ} \mathrm{C}$ (Johnson, 1956). The intertidal zones of both shores are characterised by a sandy mud substrate with high volumes of overlaying shell material. The three most abundant contributing species to substrate mixes are; Mytilus edulis, Cerastoderma edule and Artica islandica (Wilson and Lawlor, 1996). The main freshwater input into Belfast Lough is via the River Lagan, which contributes an average $E$. coli input loading of $2.1 \times 10^{12-d}$ at a mean flow of $8.521 \mathrm{~m}^{3-s}$ (CEFAS, 2017).

The River Lagan is impounded by a floodgate, the Lagan Weir, which typically only allows water exchange for $2 \mathrm{hr}$ either side of high tide. According to the water balance index there is a clear dominance of the tidal dynamics against river dynamics in the Lough. Belfast Lough is also subject to intensive anthropogenic stressors. The major industrial shipping port at the head of the Lough manages $>80 \%$ of Northern Ireland's petroleum and oil imports. Furthermore, Belfast Port handles $>7000$ vessels per year with an average freight through flow of 24.6 million tonnes. The inner lough accommodates 21 licensed blue mussel (Mytilus 
89

90

91

92

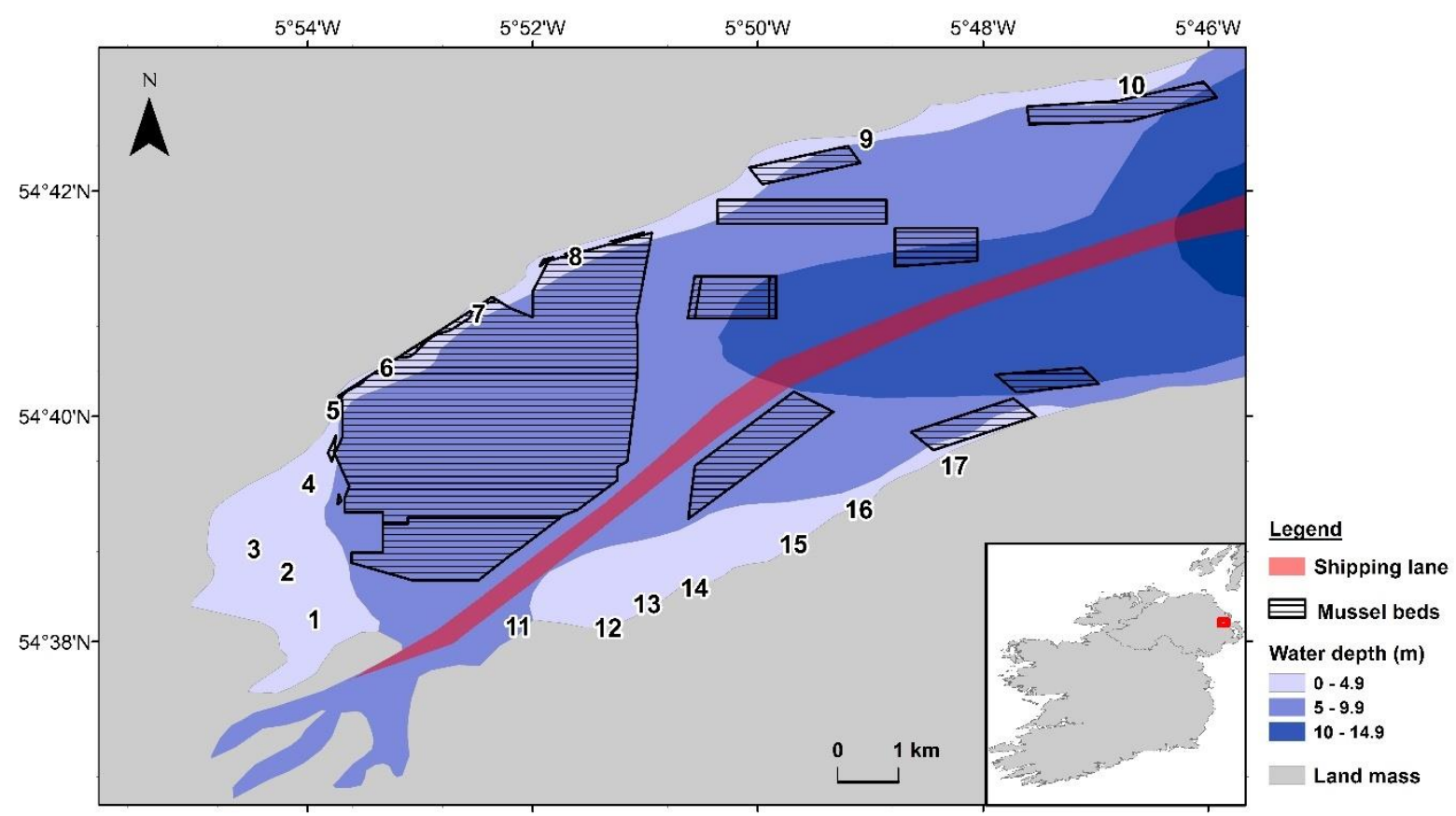

edulis) mariculture beds which are fished by dredge. Fishing activity in the outer Lough focuses on pot fishing, scallop dredging and bottom-trawling for Nephrops norvegicus (Ferreira et al., 2007).
93 
In order to ascertain if $O$. edulis had settled along the intertidal zone of the Lough, both east and west shores were surveyed between May and June 2020 using belt transects of $5 \mathrm{~m}$ carried out $1 \mathrm{~m}$ from the low water mark on tides $<0.8 \mathrm{~m}$ below datum chart. Ten $\mathrm{x} 1 \mathrm{~km}$ transects were completed along the west shore starting at Shellbank and finishing at Kilroot (Fig. 1). Dangerous sheer rock terrain and fine sand substrates limited the east shore survey to six $x 1 \mathrm{~km}$ transects starting at, Fujitsu Shore and finishing at Rock Beach (Fig. 1).

If an oyster was recorded along a transect, a 20-minute timed search was carried out at the site of settlement within a $5 \times 20$ m survey plot as per Smyth et al. (2009). Substrate type was recorded at all sites and all oyster height measurements recorded in-situ using Vernier ${ }^{\odot}$ callipers. Specimens were photographed using a Canon Powershot $\mathrm{G}^{\circ} 6^{\odot}$ on auto setting: $19 \mathrm{~mm}$ focal length, ISO $100,1 / 50$ second at $f / 5.6 .16: 9$ aspect ratio with a reference in frame for scale. Images were calibrated using Coral Point Count ${ }^{\circledR}$ as per Carleton \& Done (1995) to the suggested known overhead distance of $(1 \mathrm{~m})$. The image measuring application in $\mathrm{CPC}^{\odot}$ was applied to each image to obtain morphometric data which could be applied to the shell age associations for O. edulis cited in Richardson et al. (1993).

As this was a baseline investigation, statistical analysis was limited. However, a t-test was carried out to examine the total number of oysters recorded on the east and west shores to determine if settlement was governed by location. In order to ascertain if a difference existed in the size of oysters recorded at each site a one-way PERMANOVA was carried out between site and size of individual oysters using PAST vr3.4 ${ }^{\circledR}$ (https://folk). 
126 Within the intertidal zone of Belfast Lough, live Ostrea edulis were recorded at six sites. The

127 west shore had five sites and the greatest number of oysters with 32 individuals, the smallest

128 being $27 \mathrm{~mm}$ in length and the largest $112 \mathrm{~mm}$ (Fig 2). The size and age variations between

129 sites indicated that recruitment has been on-going within the Lough over the past 8-10 years.

130 The average age of oysters on the west shore were between 3-4 years with an average shell

131 height of $64 \mathrm{~mm}$ as per estimations from Richardson et al., (1993) (Table 1). The east shore

132 had one settlement site with nine individuals, the smallest being $33 \mathrm{~mm}$ and the largest 72

$133 \mathrm{~mm}$. The average age within the assemblage was 1-2 years with an average shell height of

$13450 \mathrm{~mm}$ (Table 1). However, it must be emphasised that there may be variations within these

135 age determinations as Richardson's research was based on O. edulis specimens from Essex

136 which sits three lines of latitude below the sites in Belfast Lough. 


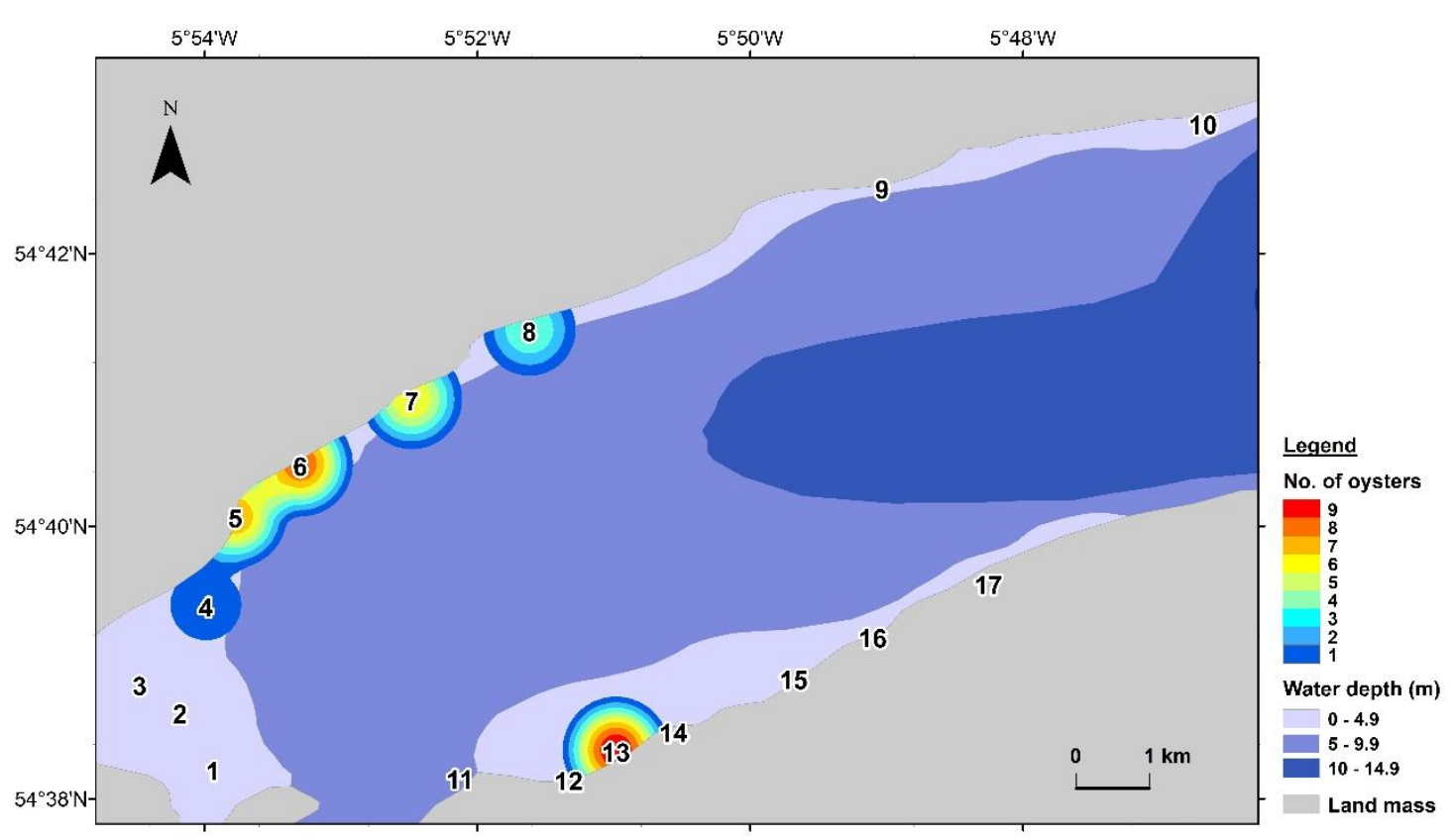

140 Fig 2. Intertidal Ostrea edulis assemblages: 4. Gideon's Green, 5. Hazelbank, 6. Whiteabbey,

141 7. Jordanstown, 8. Greenisland and 13. Kinnegar Barracks. Map generated using Arc Map

$142 \quad$ 10.7.1 spatial analysis WGS84 coordinate geometry used throughout. (British Crown and

143 OceanWise ${ }^{\odot}, 2020$. All rights reserved. Licence No. EK001-20180802. Not to be used for

144 Navigation).

146 A $t$-test was carried out using PAST vr3.4 ${ }^{\odot}$ between the total oyster abundance of west and 147 east shore assemblages, no significant difference was detected $(p>0.2)$. Furthermore, 148 PERMANOVA analysis did not detect any significant differences between oyster size and site $149 \quad(F=1.79, P>0.1)$.

150 A basic substrate description was assigned to each survey transects and live oyster sites 151 (Tables 1). Substrate component percentages within site transects are displayed in pie chart 
152 format (Fig. 3). In-situ digital stills of live oysters within the settlement survey plot are 153 presented in (Fig. 4).

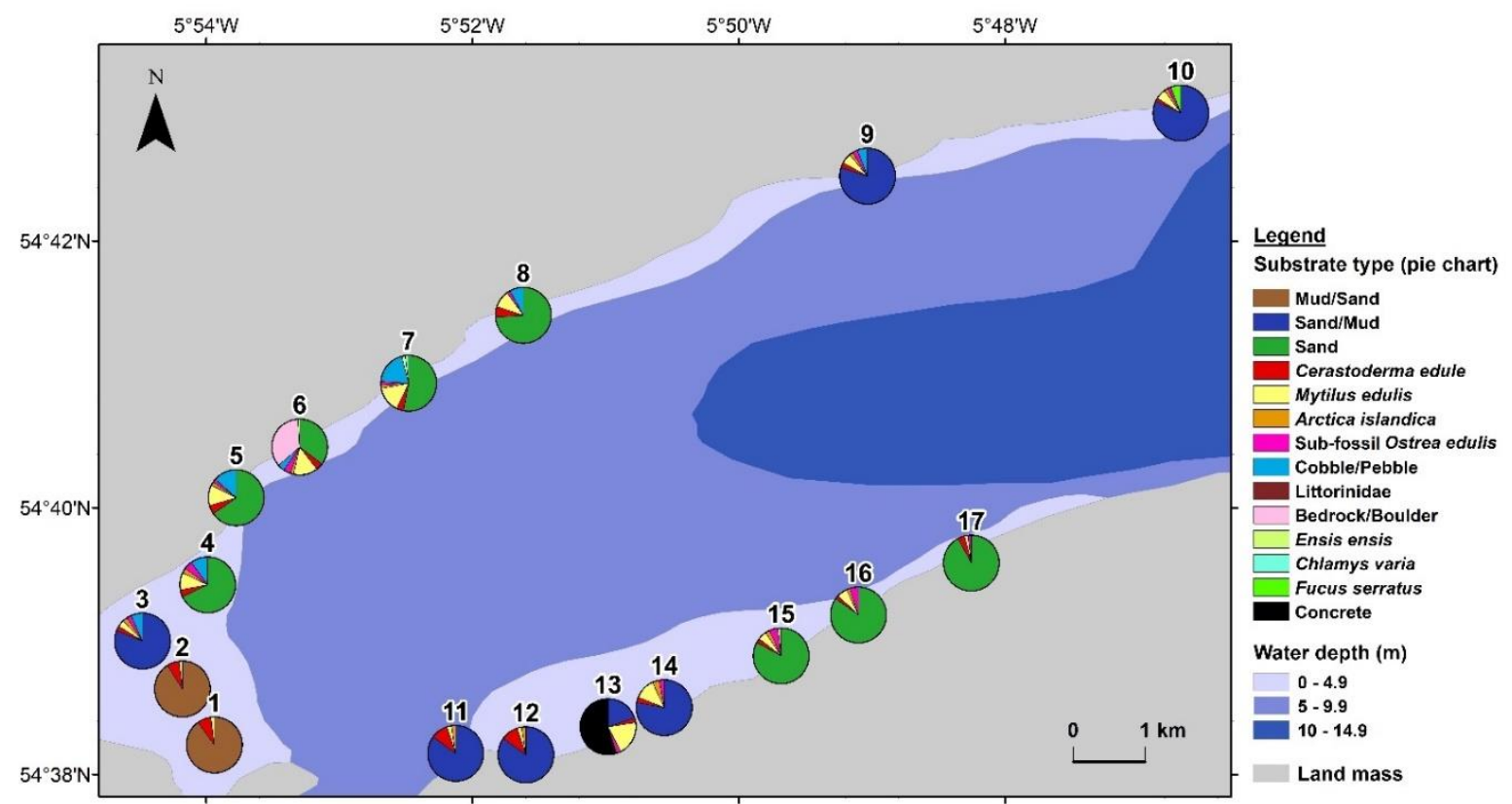

Fig 3. Substrate composition at survey sites. Oyster assemblages were recorded at sites 4-8 on the west and site 13 on the east. Map generated using Arc Map 10.7.1 spatial analysis WGS84 coordinate geometry used throughout. (British Crown and OceanWise ${ }^{\circledR}, 2020$. All rights reserved. Licence No. EK001-20180802. Not to be used for Navigation). 
abundance, size and age as per Richardson et al., (1993).

\begin{tabular}{|c|c|c|c|c|c|c|c|}
\hline \multicolumn{8}{|c|}{ Belfast Lough Survey 2020} \\
\hline \multirow{2}{*}{$\begin{array}{l}\text { Site } \\
\text { 1. Shellbank }\end{array}$} & \multirow{2}{*}{$\begin{array}{l}\text { Coordinates } \\
54.640651 \\
-5.900872\end{array}$} & \multirow{2}{*}{$\begin{array}{l}\text { Substrate type } \\
\text { Sand/mud/ } \\
\text { occasional mixed shell }\end{array}$} & \multirow{2}{*}{$\begin{array}{l}\text { No. } \\
\text { Oysters } \\
0\end{array}$} & \multirow{2}{*}{$\begin{array}{l}\text { Size } \\
\mathrm{mm}\end{array}$} & \multicolumn{3}{|c|}{$\begin{array}{l}\text { Age in years } \\
\text { min, max, mean }\end{array}$} \\
\hline & & & & & & & \\
\hline 2. Interval & $\begin{array}{l}54.643780 \\
-5.908124 \\
\end{array}$ & $\begin{array}{l}\text { Sand/mud/ } \\
\text { occasional mixed shell }\end{array}$ & 0 & 0 & 0 & 0 & 0 \\
\hline 3. Whitehouse & $\begin{array}{l}54.647411 \\
-5.907927\end{array}$ & $\begin{array}{l}\text { Sand/mud/ } \\
\text { occasional mixed shell }\end{array}$ & 0 & 0 & 0 & 0 & 0 \\
\hline $\begin{array}{l}\text { 4.Gideon's } \\
\text { Green }\end{array}$ & $\begin{array}{l}54.657021 \\
-5.899842\end{array}$ & Sand/shell mix & 2 & 37,112 & $0-1$ & $>8$ & $3-4$ \\
\hline 5. Hazelbank & $\begin{array}{l}54.662412 \\
-5.898846\end{array}$ & Sand/shell mix & 7 & $\begin{array}{l}60,63,81 \\
82,83,85 \\
87 \\
\end{array}$ & $2-3$ & $4-5$ & $3-4$ \\
\hline 6. Whiteabbey & $\begin{array}{l}54.667904 \\
-5.896265\end{array}$ & $\begin{array}{l}\text { Sand/shell } \\
\mathrm{mix} / \text { bedrock/boulder }\end{array}$ & 8 & $\begin{array}{l}27,41,56 \\
56,73,80, \\
84,85\end{array}$ & $0-1$ & $4-5$ & $3-4$ \\
\hline 7.Jordanstown & $\begin{array}{l}54.675380 \\
-5.890914 \\
\end{array}$ & Sand/shell mix/cobble & 6 & $\begin{array}{l}38,38,42 \\
63,67,77\end{array}$ & $0-1$ & $3-4$ & $1-2$ \\
\hline 8. Greenisland & $\begin{array}{l}54.690979 \\
-5.861021\end{array}$ & Sand/shell mix/cobble & 9 & $\begin{array}{l}33,46,48 \\
51,57,64 \\
80,82,82 \\
\end{array}$ & $0-1$ & $4-5$ & $2-3$ \\
\hline 9.Carrickfergus & $\begin{array}{l}54.708104 \\
-5.817230 \\
\end{array}$ & $\begin{array}{l}\text { Sand/mud/cobble/ } \\
\text { occasional mixed shell }\end{array}$ & 0 & 0 & 0 & 0 & 0 \\
\hline 10. Kilroot & $\begin{array}{l}54.718930 \\
-5.765505 \\
\end{array}$ & $\begin{array}{l}\text { Sand/mud/Fucus/ } \\
\text { occasional mixed shell }\end{array}$ & 0 & 0 & 0 & 0 & 0 \\
\hline 11. Fujitsu & $\begin{array}{l}54.635956 \\
-5.868799 \\
\end{array}$ & $\begin{array}{l}\text { Sand/mud/occasional } \\
\text { mixed shell }\end{array}$ & 0 & 0 & 0 & 0 & 0 \\
\hline $\begin{array}{l}\text { 12. Kinnegar } \\
\text { Treatment }\end{array}$ & $\begin{array}{l}54.635771 \\
-5.855509\end{array}$ & Sand/mud/mixed shell & 0 & 0 & 0 & 0 & 0 \\
\hline $\begin{array}{l}\text { 13. Kinnegar } \\
\text { Barracks }\end{array}$ & $\begin{array}{l}54.639278 \\
-5.849715\end{array}$ & $\begin{array}{l}\text { Sand/mud/mixed } \\
\text { shell/concrete }\end{array}$ & 9 & $\begin{array}{l}28,35,42 \\
45,53,55 \\
56,61,72 \\
\end{array}$ & $0-1$ & $2-3$ & $1-2$ \\
\hline $\begin{array}{l}\text { 14. Holywood } \\
\text { Yacht Club }\end{array}$ & $\begin{array}{l}54.641671 \\
-5.842687 \\
\end{array}$ & $\begin{array}{l}\text { Mud/sand/occasional } \\
\text { mixed shell }\end{array}$ & 0 & 0 & 0 & 0 & 0 \\
\hline 15.SeaPark & $\begin{array}{l}54.648139 \\
-5.828045 \\
\end{array}$ & Sand/shell mix & 0 & 0 & 0 & 0 & 0 \\
\hline 16.RoyalNorth & $\begin{array}{l}54.653253 \\
-5.818363 \\
\end{array}$ & Sand/shell mix & 0 & 0 & 0 & 0 & 0 \\
\hline 17.RockBeach & $\begin{array}{l}54.659749 \\
-5.804232\end{array}$ & $\begin{array}{l}\text { Sand/occasional mixed } \\
\text { shell }\end{array}$ & 0 & 0 & 0 & 0 & 0 \\
\hline
\end{tabular}




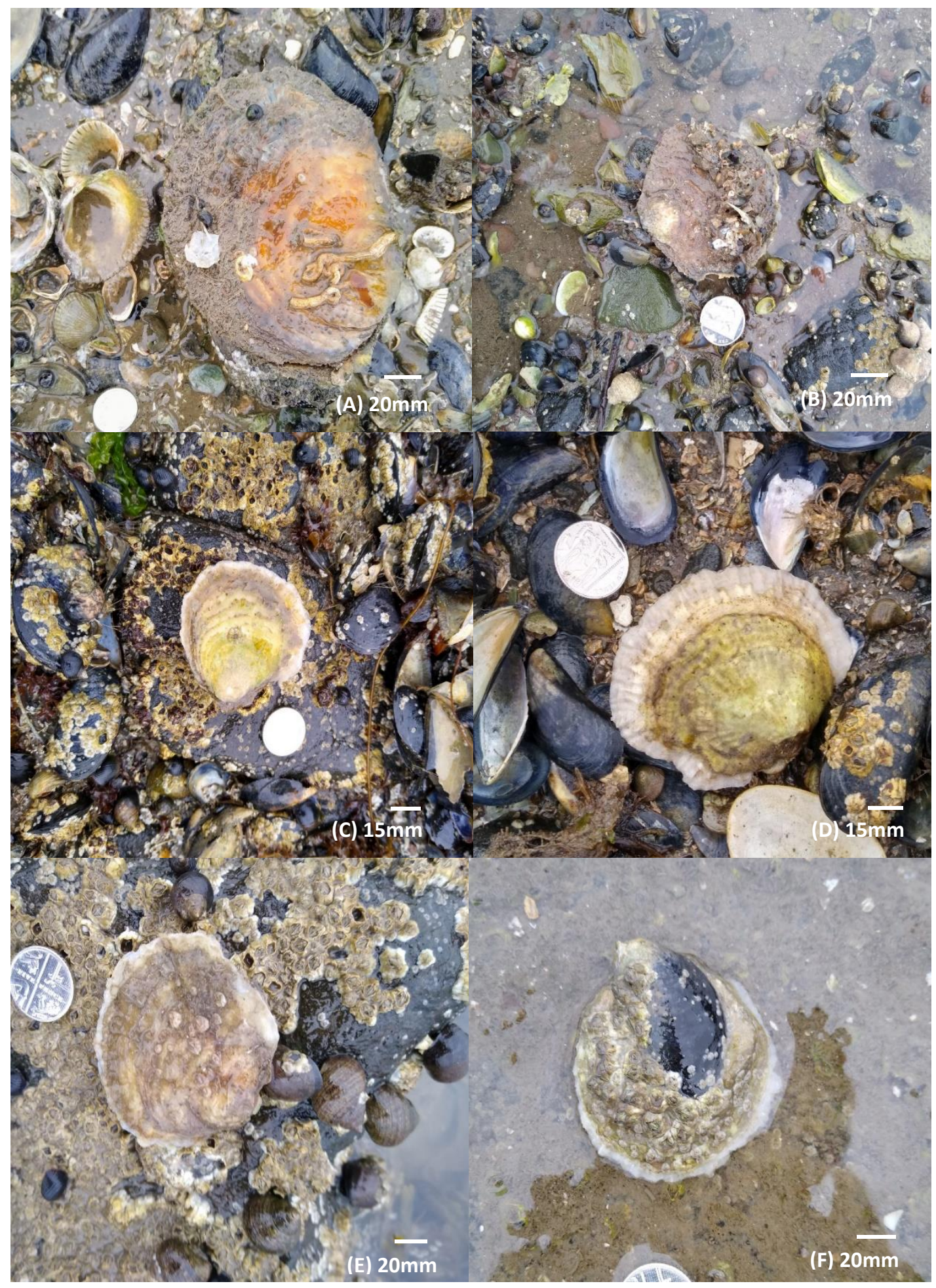

Fig. 4. Examples of settled Ostrea edulis at sites; A. Gideon's Green, B. Hazelbank, C.

Whiteabbey, D. Jordanstown, E. Greenisland and F. Kinnegar Barracks. 
173 Unsubstantiated reports of solitary European flat oysters on the shores of Belfast Lough suggested that Ostrea edulis had returned to the waterway after more than a century of absence and the findings presented here have categorically shown that this is indeed the case.

A total of 42 oysters were recorded with sizes ranging from $28-112 \mathrm{~mm}$ indicating a population consisting of both 0-1-year juveniles and adults of $>8$ years (Richardson et al., 1993). These variations in age are significant and indicate that recruitment had been taking place unnoticed within the Lough for at least 8-10 years.

While the number of oysters does not signify a sustainable population, it does raise questions as to; where did they come from and what allowed the settlement of larvae to occur? There have been no attempts at 0 . edulis aquaculture within the Lough's catchment and therefore the recent settlements must have been incidental. An understanding of recent abiotic and biotic changes within the Lough may offer some explanations as to how $O$. edulis has managed to make a return. An, important recent development within the Lough to be noted before assumptions are made occurred in 2016 with the dredging of the central channel. This was carried out to accommodate an increase in shipping traffic which had been steadily growing since 2000 when 5,336 vessels visited Belfast Port to > 6,800 in 2018 (DoT 2018). As a result, $>400,000 \mathrm{~m}^{3}$ of dredge spoil were removed to widen the main shipping routes and accommodate deeper drafts and (BHA, 2018). 
The hypothesis that shipping ballast water spreads molluscan species has been postulated since the late 1800s (Sassi et al., 2005) and is now a well-documented route for invasive and native species into new areas (Endresen et al., 2004; Bailey, 2015). The transportation of the Pacific oyster Magallana gigas larvae has been periodically detected in ballast water sources cause of $C$. gigas introductions into the east coast of Scotland as there had been no aquaculture ventures for the species in the region (Smith et al., 2014).

The increases in shipping to Belfast Port over the last decade offer the possibility for a ballast rare and mortalities within the pelagic stage of the life cycle are considerable (Korringa, 1941).

A more probable explanation is that adult oysters were introduced through the commercial over a number of plots located either side of the shipping channel (CEFAS, 2017). The fishery plots are seeded with juvenile mussels dredged from various locations in the Irish Sea (Ferreira et al., 2007). It may be that within some of the dredged seed that a number of fecund O. edulis were collected and relayed (Wolff and Reise, 2002). However, the translocation of seed mussel has been carried out for $>30$ years with no 0 . edulis settlements recorded. Therefore, if the mariculture plots have been the source of oyster larvae, it must have been

214 from seed deployed within the last ten years. This is significant as records of the seed mussel site locations for the 2008, 2009 and 2010 relays may reveal a possible undiscovered Irish Sea population of native oysters. 
In addition, abiotic or biotic changes within Lough over the last 10 years could have created conditions conducive to promoting the pooling and settlement of oyster larvae. Recent bathometric changes through the deepening of the central shipping channel and the resulting subsequent alterations to fine-scale hydrodynamics, may offer an explanation. However, finescale particle tracking and hydrodynamic modelling of the watercourse would be required to confirm this theory and unfortunately this was economically beyond the resources of our short survey.

\subsection{Settlement}

Belfast Port sits at the head of the Lough and is the largest commercial harbour in Northern Ireland. Anthropogenically introduced disturbances such as dredging are often associated with detrimental changes in marine habitats (Demes et al., 2012). However, in the case of Belfast Lough the increases in shipping and the subsequent dredging induced bathymetrical changes may have created a situation whereby the hydrodynamic regimen is now in a position to once again permit $O$. edulis larval settlements.

Increases in vessel activity and their subsequent wakes in particular have been shown to be instigators of environmental change within soft sediment benthic communities (Payne et al., 1999). Wake generated water velocity has led to instances of increased siltation in shallow estuarine systems and the subsequent smothering of bivalve beds and the burying of hardshell substrates (Berghahn and Ruth, 2005). However, this is not always the situation and a number of factors need to be considered when assessing the effects of vessel wakes. Sediment composition, channel geometry, distance to shore, the number of successive vessels and their speed of passage can all influence wake effects (Gabel et al., 2017). 
Demes et al., (2012) showed in British Columbia that primary production actually increased on rocky shore sites which lay favourable distances from intermittent ferry wake pulses. The distance from the wake's origin can have a significant influence on the degree of environmental stress. In some instances, Crassostrea virginica oyster reef systems in 244 shallower estuarine regions were displaced by wakes with heights as shallow as $2 \mathrm{~cm}$ 245 (Campbell, 2014). However, wakes were shown to have had no impact on recruitment. 246 Indeed, the dislodgement of oyster assemblages may have actually aided the geographical expansion of C. virginica within estuaries (Wall et al., 2005; Campbell, 2014).

The combined effect of regular wake travel to and from the shore can result in cleaning substrate surfaces of sediment through a washing effect (Koelh et al., 2013). This process can lead to increases in species abundance and richness along intertidal zones which are situated sufficiently far enough from the initial high velocity water pulse (Gabel et al., 2017).

The study presented here, revealed no oyster settlement close to the Port entrance even though shell substrate was substantial. Therefore, the speculation that the mariculture plots were a source of larvae becomes ever more likely as settlements were localised to sites within the boundaries of the mussel fishery lays and between 3-7 km from the head of the Lough. A distance which appears to have been suitably far enough from initial wake amplitude to allow shell substrates to remain clear of siltation, while tidal water retention remained sufficient to enable $O$. edulis pediveligers the opportunity to undergo cementation. The provision of clean settlement material and sufficient water retention have been recognised as optimal for larvae to settle and metamorphose (Cole and Knight-Jones, 1949; Waugh, 1972; Foster, 1994; Smyth et al., 2017). 
The substrate mixes along Lough's intertidal zones provide some excellent settlement areas,

263 however the findings of the survey identified assemblages in close proximities to each other. Suggesting, that the assumptions as to how the native oysters returned is not confined to one factor but to a combination of the proposed hypothesises. The unassisted reoccurrence of native oysters in Belfast Lough is undoubtably a unique event with many questions needing addressed before a pathway of re-establishment can be confirmed.

\section{Conclusion}

The 2020 documented settlements of $O$. edulis in Belfast Lough have raised a number of interesting hypotheses. Further research as to how the return of the oyster was induced is required. In-depth investigations into the effects of pollution and dredging impacts were practically and financially beyond the scope of this study. The main aim of this manuscript was to document that oysters are once again present in Belfast Lough after a century of absence. The initiation of future studies should be considered a matter of urgency, as a better understanding of abiotic and biotic parameters within the Lough could greatly benefit numerous European native oyster restoration projects which are currently underway.

\section{Acknowledgments}

This work was supported by the Shellfish Centre RD\&I operation, part-funded by the EU'S West Wales and the Valleys European Regional Development Fund (ERDF) Operational Programme through the Welsh Government. We are particularly grateful to Mr L. McCay, Miss R. McCay, Dr L. Gilmore and Ms. K. Hewitt for their input into the survey work. We would 
also like to offer our thanks to the reviewers of this manuscript for their constructive suggestions which greatly improved the content.

286

\section{References}

Bailey, S.A., 2015. An overview of thirty years of research on ballast water as a vector for aquatic invasive species to freshwater and marine environments. Aquat Ecosyst Health \& Manag, 18, 261-268. https://doi.org/10.1080/14634988.2015.1027129.

Beck, M.W., Brumbaugh, R.D., Airoldi, L., Carranza, A., Coen, L.D., Crawford, C., Defeo, O., Edgar, G.J., Hancock, B., Kay, M.C., Lenihan, H.S., Luckenbach, M.W., Toropova, C.L., Zhang,

G., Guo X., 2011. Oyster reefs at risk and recommendations for conservation, restoration, and management. Bioscience, 61, 107-116. https://doi.org/10.1525/bio.2011.61.2.5.

296

Berghahn, R., Ruth, M., 2005. The disappearance of oysters from the Wadden Sea: a cautionary tale for no-take zones. Aquat Conserv, 15, 91-104.

https://doi.org/10.1002/aqc.635.

Belfast Harbour Authority (BAH) 2018. Annual Report \& Accounts - Belfast pp. 18-19.

Harbourwww.belfast-harbour.co.uk.

file://C:/Users/dvs19nqc/Downloads/Belfast\%20Harbour\%20Annual\%20Report\%20Web\%2 0(2).pdf (accessed 27 June 2020)

Browne, T., 1903. Report on the shellfish laying's on the Irish Coast, Inspector of Irish

Fisheries, His Majesty's Stationery Office Dublin

Campbell, D., 2014. Quantifying the effects of boat wakes on intertidal oyster reefs in a shallow estuary, MS thesis, University of Central Florida 
Carleton, J.H., Done, T.J., 1995. Quantitative video sampling of coral reef benthos: largescale application. Coral Reefs, 14, 35-46. https://doi.org/10.1007/BF00304070.

Centre for Environment Fisheries and Aquaculture Science (CEFAS), 2007. Belfast Lough Sanitary Review. Report for The Food Standards Agency in Northern Ireland. FSA NI, C5792H. https://www.cefas.co.uk/data-and-publications/sanitary-surveys/northern-ireland/

Cole, J., Knight-Jones, E., 1949. The setting behaviour of larvae of the European flat oyster Ostrea edulis L., and its influence on methods of cultivation and spat collection, Ministry of Agriculture and Fisheries Investigation Series II, 17, pp. 3-39

Demes, K.W., Kordas, R.L., Jorve J.P., 2012. Ferry wakes increase seaweed richness and abundance in a sheltered rocky intertidal habitat. Hydrobiologia, 693 (1), 1-11. https://doi.org/10.1007/s10750-012-1082-4.

Department of Transport UK Ports, 2018. Port and domestic freight statistics: PORT Report for UK Government 0501 pp 4.

https://assets.publishing.service.gov.uk/government/uploads/system/uploads/attachment_ data/file/826446/port-freight-statistics-2018.pdf.

Endresen, $\varnothing$., Behrens, H.L., Brynestad, S., Andersen, A.B., Skjong R., 2004. Challenges in global ballast water management. Mar. Pollut. Bull. 48 (7-8), 615-623.

https://doi.org/10.1016/j.marpolbul.2004.01.016.

Farinas-Franco, J.M., Pearce, B., Mair, J.M., Harries, D.B., MacPherson, R.C., Porter, J.S., Reimer, P.J., Sanderson W.G., 2018. Missing native oyster (Ostrea edulis L.) beds in a European Marine Protected Area: Should there be widespread restorative management? Biol. Conserv. 221, 293-311. https://doi.org/10.1016/j.biocon.2018.03.010. 
Ferreira, J.G., Hawkins, A.J.S., Monteiro, P., Moore, H., Edwards, A., Goven, R., Lourenco, P., A., Mellor, Nunes, J.P., Ramos, L., Sequeiro, A., Strong J., 2007. SMILE - sustainable mariculture in northern Irish lough ecosystems: assessment of carrying capacity for environmentally sustainable shellfish culture in Carlingford Lough, Strangford Lough, Belfast Lough, Larne Lough and Lough Foyle. Institute of Marine Research

Foster, J., 1994. Chesapeake Bay benthic rehabilitation-rebuilding oyster reefs. Bull. Mar. Sci. 55, 1335.

Gabel, F., Lorenz, S., Stoll S., 2017. Effects of ship-induced waves on aquatic ecosystems. Sci. Tot. Env. 601-602, 926-939. https://doi.org/10.1016/j.scitotenv.2017.05.206.

Gee, J., Wilson, K., 1981. The Littoral Mollusca of Green island, Co Antrim: 40 Years of Change in Belfast Lough. Ir. Nat. J. 20 (8), 343-345. https://archive.org/stream/biologicalbullet180mari/biologicalbullet180mari_djvu.txt individual distance in conserving the European oyster Ostrea edulis. J. Mar. Biolog. 99 (3), 587-593. https://doi.org/10.1017/S0025315418000395.

360

Helmer, L.D., Farrell, P., Hendy, I., Harding, S., Robertson, M., Preston J., 2019. Active management is required to turn the tide for depleted Ostrea edulis stocks from the effects of overfishing, disease and invasive species. PeerJ, 7, e6431. https://doi.org/10.7717/peerj.6431. https://doi.org/10.2014/igj.v3i3.1129. 
Kennedy, R., Roberts D., 1999. A Survey of the current status of the flat oyster Ostrea edulis in Strangford Lough, Northern Ireland, with a view to the restoration of its oyster beds. Acad. Biol. and Environ. Proceedings of the Royal Irish Academy, 99 (B), 79-88.

Kennedy, R., Roberts, D., 2006. Commercial oyster stocks as a potential source of larvae in the regeneration of Ostrea edulis in Strangford Lough, Northern Ireland. J. Mar. Biolog. 86 (1), 153-159. https://doi.org/10.1017/S0025315406012963.

Koelh, M.A.R., Crimaldi, J.P., Dombroski, D.E., 2013. Wind chop and ship wakes determine hydrodynamic stresses on larvae settling on different microhabitats in fouling communities. Mar. Ecol. Prog. Ser. 479, 47-62. https://doi.org/10.3354/MEPS10193.

Korringa, P., 1941. Experiments and observations on swarming, pelagic life and setting in the European Flat oyster, Ostrea edulis. Extrait des Archives Neerlandaises de Zoologie, 5. 1-249.

Korringa, P., 1946. The decline of natural oyster beds. Basteria 10, 36-41.

Maggenis, B.A, Gosling, E., Wilkins, N.P., 1983. Irish oyster populations: a historical and genetic study. Proceedings of the Royal Irish Academy. 83b, 291-299.

Mair, L.W.D., 1908. Enteric and typhoid fever in Belfast, in Report to the Local Government Board for Ireland Belfast Health Commission, Dublin, pp. 103-141.

Miskimin, S., 1829. The history and antiquities of the Council of the Town of Carrickfergus. A statistical survey. British Library Belfast Press.

Parr, J., Ager, O.E.D., 2003. Collation of data on distribution of species and habitats in the Irish Sea - Stage 2. Report from the Marine Biological Association to the Joint Nature Conservation Committee, (JNCC Contract: F90-01-592) 
Patil, J.G., Gunasekera, R.M., Deagle, B.E., Bax, N.J., 2005. Specific detection of Pacific oyster 400 (Crassostrea gigas) larvae in plankton samples using nested polymerase chain reaction. Mar.

402

403

Payne, B.S., Miller, A.C., Shaffer, L.R., 1999. Physiological Resilience of Freshwater Mussels

to Turbulence and Suspended Solids. J. Freshw. Ecolo. 14. 265276.

405

https://doi.org/10.1080/02705060.1999.9663678

406

407

Pogoda, B., 2019. Current status of European oyster decline and restoration in Germany. Humanit. 8(1), 9. https://doi.org/10.3390/h8010009.

409

Pogoda, B., Brown, J., Hancock, B., Preston, J., Pouvreau, S., Kamermans, P., Sanderson, W., von Nordheim H., 2019. The Native Oyster Restoration Alliance (NORA) and the Berlin Oyster Recommendation: bringing back a key ecosystem engineer by developing and supporting best practice in Europe. Aquat. Living Resour. 32, 13. https://doi.org/10.1051/alr/2019012.

Richardson, C.A., Collis, S.A., Ekaratne, K., Dare, P., Key D., 1993. The age determination and growth rate of the European flat oyster, Ostrea edulis, in British waters determined from acetate peels of umbo growth lines. ICES J. Mar. Sci. 50 (4) 493-500.

420

Sassi, J., Viitasalo, S., Rytkonen, J., Leppakoski, E., 2005. Experiments with ultraviolet light, ultrasound and ozone technologies for onboard ballast water treatment. VTT Tiedotteita, 2313. 80. ISBN 951-38-6748- X. http://www.vtt.fi/inf/pdf/tiedotteet/2005/T2313.pdf. (accessed 27 June 2020). 
Smith, I.P., Guy, C., Donnan, D., 2014. Pacific oysters, Crassostrea gigas, established in Scotland. Aquat. Conserv. 25, 733-742. https://doi.org/10.1002/aqc.2483.

Smyth, D., Roberts, D., Browne, L., 2009. Impacts of unregulated harvesting on a recovering stock of native oysters (Ostrea edulis). Mar. Pollut. Bull. 58, 916-922. https://doi.org/10.1016/j.marpolbul.2008.12.021.

Smyth, D., Mahon, A.M., Roberts, D., Kregting, L., 2017. Settlement of Ostrea edulis is determined by the availability of hard substrata rather than its nature: implications for stock recovery and restoration of the European oyster. Aquat. Conserv. 28, 3. https:// doi.org/10.1002/aqc.2876.

Smyth, D., Millar, R., Hayden-Hughes, M., Joyce, P., Royan, E., Horne, N., Kregting, L., 2020. Wild gregarious settlements of Ostrea edulis in a semi-enclosed Sea Lough; a case study for unassisted restoration. Restor. Ecol. 28, 645-654. https://doi.org/10.1111/rec.13124.

Thurstan, R.J., Hawkins, J.P., Raby, L., Roberts, C.M., 2013. Oyster (Ostrea edulis) extirpation and ecosystem transformation in the Firth of Forth Scotland. J. Nat. Conserv. 21 (5) 253-261. https://doi.org/10.1016/j.jnc.2013.01.004.

Wall, L.M., Walters, L., Grizzle, R., Sacks, P.E., 2005. Recreational boating activity and its impact on the recruitment and survival of the oyster Crassostrea virginica on intertidal reefs in Mosquito Lagoon, Florida. J. Shellfish Res. 24, 965-973. https://doi.org/10.2983/07308000(2005)24[965:RBAAII]2.0.CO;2.

Waugh, G.D., 1972. Settlement of Ostrea edulis (L.) related to the cultivation of oyster grounds, Vol. 27, Ministry of Agriculture, Fisheries \& Food Fishery Investigations Series II, London, pp. 21-33 
455 Williams, G., 1954. Fauna of Strangford Lough and Neighbouring Coasts, Proceedings of the 456 Royal Irish Academy. 56, 29-133.

457

458 Wilson, J.G., Lawlor, I., 1996. Irish marine habitats. In J.D. Reynolds (ed), The Conservation of 459 Aquatic Systems. Royal Irish Academy, 47-55.

460

461 Wolff, W.J., Reise, K., 2002. Oyster Imports as a Vector for the Introduction of Alien Species

462 into Northern and Western European Coastal Waters. In: E. Leppäkoski, S. Gollasch, S.

463 Olenin S (eds) Invasive Aquatic Species of Europe. Distribution, Impacts and Management.

464 Springer, Dordrecht

465

466 Yonge, C.M., 1960. Oysters, 2nd edition. Collins, London.

467

468

http://www.habitas.org.uk/priority/species.asp?item $=642$

469

470

https://folk.universitetetioslo.no/ohammer/past/past3manual

471 